\title{
Indigenous knowledge of bamboos by Naga community, Tasikmalaya District, West Java, Indonesia
}

\author{
BUDI IRAWAN ${ }^{1,3}$, RUHYAT PARTASASMITA ${ }^{1, \bullet}$, NGESTI RAHAYU ${ }^{2}$, TIA SETIAWATI ${ }^{1}$, JOHAN ISKANDAR $^{1}$ \\ ${ }^{1}$ Department of Biology, Faculty of Mathematics and Natural Sciences, Universitas Padjadjaran. Jl. Raya Bandung-Sumedang Km 21, Jatinangor, \\ Sumedang 45363, West Java, Indonesia. Tel. +62-22-7796412 ext. 104. Fax. +62-22-7794545.`email: rp2010rikkyo@ gmail.com; \\ ruhyat.partasasmita@unpad.ac.id \\ ${ }^{2}$ Program of Biology, Faculty of Mathematics and Natural Sciences, Universitas Padjadjaran. J1. Raya Bandung Sumedang Km. 21, Jatinangor, \\ Sumedang 45363, West Java, Indonesia \\ ${ }^{3}$ Progam in Environmental Science, Graduate School, Universitas Padjadjaran. Jl. Dipati Ukur No 35, Bandung 40134, West Java, Indonesia
}

Manuscript received: 19 March 2019. Revision accepted: 28 April 2019.

\begin{abstract}
Irawan B, Partasasmita R, Rahayu N, Setiawati T, Iskandar J. 2019. Indigenous knowledge of bamboos by Naga community, Tasikmalaya District, West Java, Indonesia. Biodiversitas 20: 1423-1434. Naga community is recognized as one of Sundanese traditional groups who reside in Neglasari village, Salawu Subdistrict, Tasikmalaya District, West Java Province, Indonesia. This community has been holding firm customs and culture. For daily needs, they take advantage of plant diversity around their homes, including bamboo. The aim of this study was to investigate the diversity (species and variations/landraces), utilization and management of bamboo among Naga community. The method used in this study was mixed method by combining qualitative and quantitative data collection with ethnobotany approach used in ethnobotanical studies. Semi-structured or deep interview, structured interviews, and participant observation method were used to collect data in the field. The result of study showed that there were 7 species and landraces of bamboos, namely Bambusa vulgaris Schard ex Wendl. var. vulgaris (haur hejo), Bambusa vulgaris Schard ex Wendl. var. striata (Lodd. ex Lindley) Gamble (haur koneng), Gigantochloa apus (J.A. \& J.H. Schult) Kurz. (awi tali), Gigantochloa pseudoarundinacea (Steud) Widjaja (awi gedelawi gombong), Gigantochloa atter (Hassk) Kurz. (awi temen), Gigantochloa atroviolacea Widjaja (awi hideung) and Schizostachyum iraten Steud (awi tamiyang) were documented and used in the gardens of Naga communities. Bamboos are traditionally used as building materials, woven for container, traditional musical instruments, equipment for cooking, agricultural and livestock tools, foodstuffs, and others. Bamboo plants in the garden have been traditionally managed which consists of land preparation, planting, maintenance, pest control, harvesting, and utilization. The conservation of bamboos has been traditionally done by Naga community, including selective cutting of bamboo trees instead of clear-cutting, and keeping the bamboos garden not being converted to other land uses.
\end{abstract}

Keywords: Bamboo, Naga community, diversity, utilization, management

\section{INTRODUCTION}

Bamboos are widely recognized as multi-functional plant and have important role for people's life in Indonesia. Bamboos have various ecological, socio-economic and cultural benefits. In term of economic values, bamboos are commonly used for various building materials and constructions, plywood, household appliances, pulp and paper materials, food sources, craft materials, traditional music instruments, ornamental plants, and traditional medicines (Dransfield and Widjaja 1995; Arinasa 2005; van der Lugt and Lobokinov 2008; Vogtlander et al. 2010). Regarding ecological functions, bamboos deliver various ecological services, including protection of soil erosion, protection of landslides, restoring soil fertility through the accumulation of organic matter and nutrients, storing carbon and producing oxygen, and providing wild animal habitats (Christanty 1989; Van der Lugt et al. 2010; Weijun et al. 2014; Buckingham et al. 2014, Nath et al. 2015). In addition to ecological and socio-economic benefits, bamboos have also various cultural values, including being used as traditional rituals in rice farming and other rituals (Iskandar 1998; Iskandar and Iskandar
2017; Arinasa and Peneng 2013; Sujarwo 2018). Because bamboo trees have been predominantly used by village people for various purposes, including fire woods and building materials, the cutting woods in the forest are lower (Nadeak 2009). It has been documented that there are more than 1,400 bamboo species of 115 genera in the world (BPG 2012; Kelchner 2013). For Indonesia, it has been recorded about 143 bamboo species that are predominantly cultivated in Java, Bali, and Sulawesi (Widjaja 2001).

Naga community who reside in Naga Hamlet, Neglasari village have been widely recognized as one of the traditional communities in West Java which have still maintained various traditional aspects, including practicing the cultivation of bamboos. Although Naga community have been decided as one of the tourist destinations in West Java based local regulation (Perda) No. 2 concerning the spatial plans of Tasikmalaya District, Naga community have been still holding their customs by passing down their culture, traditions, customs, and practices from generation to generation. For example, although many visitors come to Naga Hamlet for tourism, some negative aspects caused by tourism development can be avoided (Munawaroh and Astuti 2000). 
Naga community have been traditionally cultivating various plants, including bamboo species in mixed garden (kebon campuran) based on their traditional ecological knowledge which is strongly embedded in their culture (cf. Bekes 2008; Iskandar 2018). Some studies on traditional ecological knowledge have conducted by scholars, including studies on village chickens and local rice varieties (Partasasmita et al. 2017b; Permana et al. 2018; Iskandar and Iskandar 2018). Nonetheless, studies on traditional ecological knowledge on bamboos in Naga Hamlet have not yet been undertaken. As such, study on this topic is considered to be important.

The aim of this study was to investigate traditional ecological knowledge on the diversity (species and variations/landraces), utilization and management of bamboo among Naga community.

\section{MATERIALS AND METHODS}

\section{Area of study}

Naga community who reside in Naga Hamlet have been known as one of the traditional communities in West Java. They have very close interaction with their environment. The community manages their environment based on traditional ecological knowledge or local knowledge and cosmos or beliefs.

Naga Hamlet consists of one neighborhood ( $R T=$ Rukun Tetangga) which administratively belongs to Neglasari Village, Sub-district of Salawu, Tasikmalaya District, West Java Province, Indonesia (Figure 1).

Geographically, Naga Hamlet is located at $107^{\circ} 3^{\text {' East }}$ longitude and $7^{\circ} 1$ ' South latitude. The hamlet is placed in a valley area surrounded by hills stretching from east to west (Yulianingsih 2002; Profile of Neglasari village 2017). The total is of Naga Hamlet settlement is recorded approximately 1.5 hectares. Naga Hamlet is bordered to west by graves (makam) and sacred forest (leuweung karamat), Ciwulan river and Cigalontang Sub-district, while to north and south are bordered by ditch and wet rice fields (sawah).

Land use type of Naga Hamlet consists of settlement, agricultural land, and river. The hamlet is located in a valley where traditional houses on stilts are placed at its center and homegarden is more open and planted with plants scattered particularly on the edge and back of the houses. On the outside of the settlement, there are fish ponds with traditional bath sower where various freshwater fishes are raised, including common carp (Cyprinus carpio), mujair (Oreochromis mossambicus), and nila (Oreochromis niloticus). On the outside of the fish ponds, there are wet rice fields cultivated with mixed rice varieties, local and modern varieties, while the hills are planted with various annual and perennial crops, including bamboos in the form of traditional agroforestry system of mixed-garden (Figure 2.A-B).

Based on its tradition, the landscape of Naga Hamlet can be divided into 3 zones, namely holy area (kawasan suci), clean area (kawasan bersih) and dirty area (kawasan kotor) (Iskandar 2012, 2017; Sarigendyanti 2008). The holy area is considered to be not freely visited by anyone. This is must be carefully protected by all people of Naga community. The holly area is located in the west of the settlement, consisting of protected forest (leuweung larangan) where ancestral graves of Naga community are placed (Iskandar 2017).
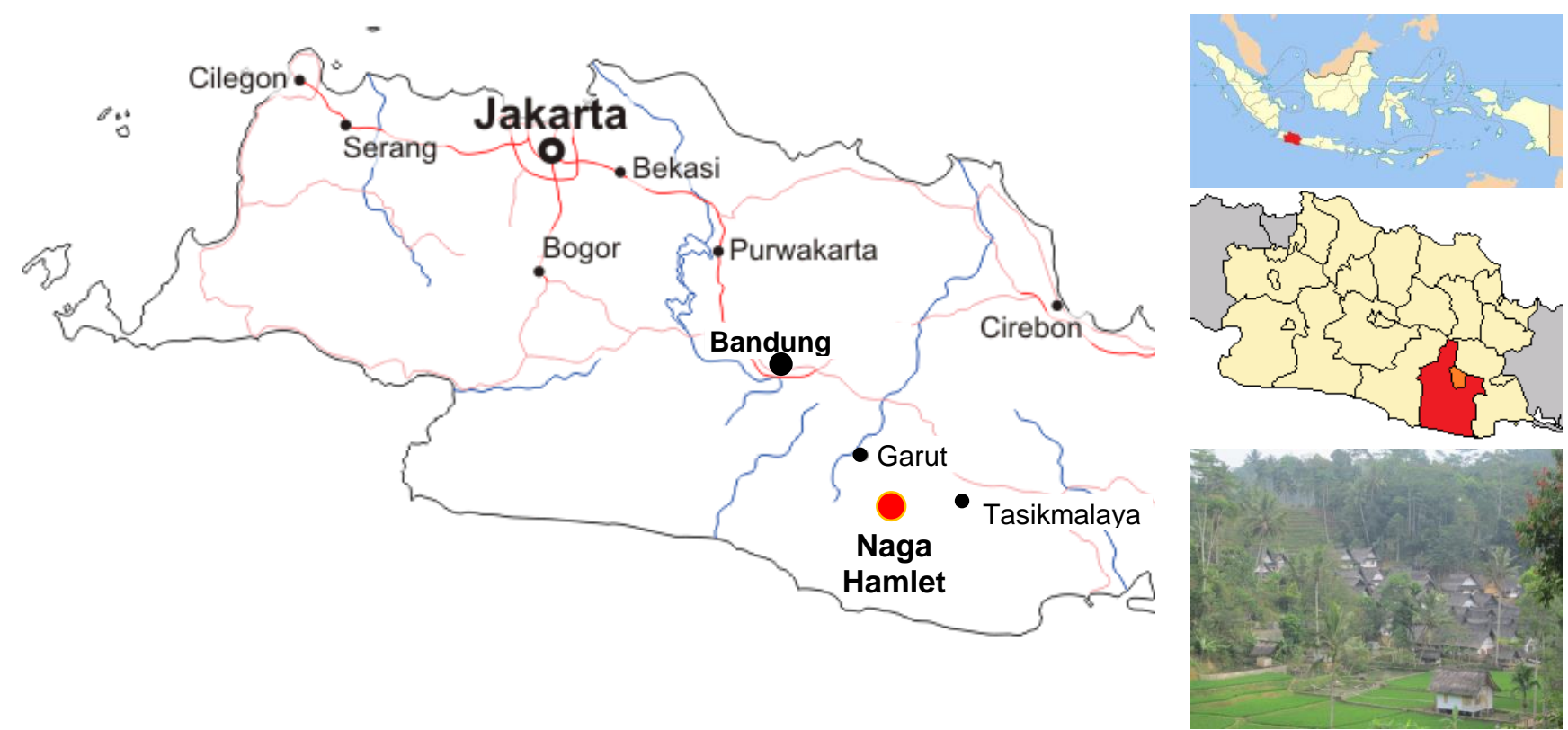

Figure 1. Map of Naga Hamlet located in Neglasari Village, Salawu Sub-district, Tasikmalaya District, West Java Province, Indonesia (Partasasmita et al. 2017b). 


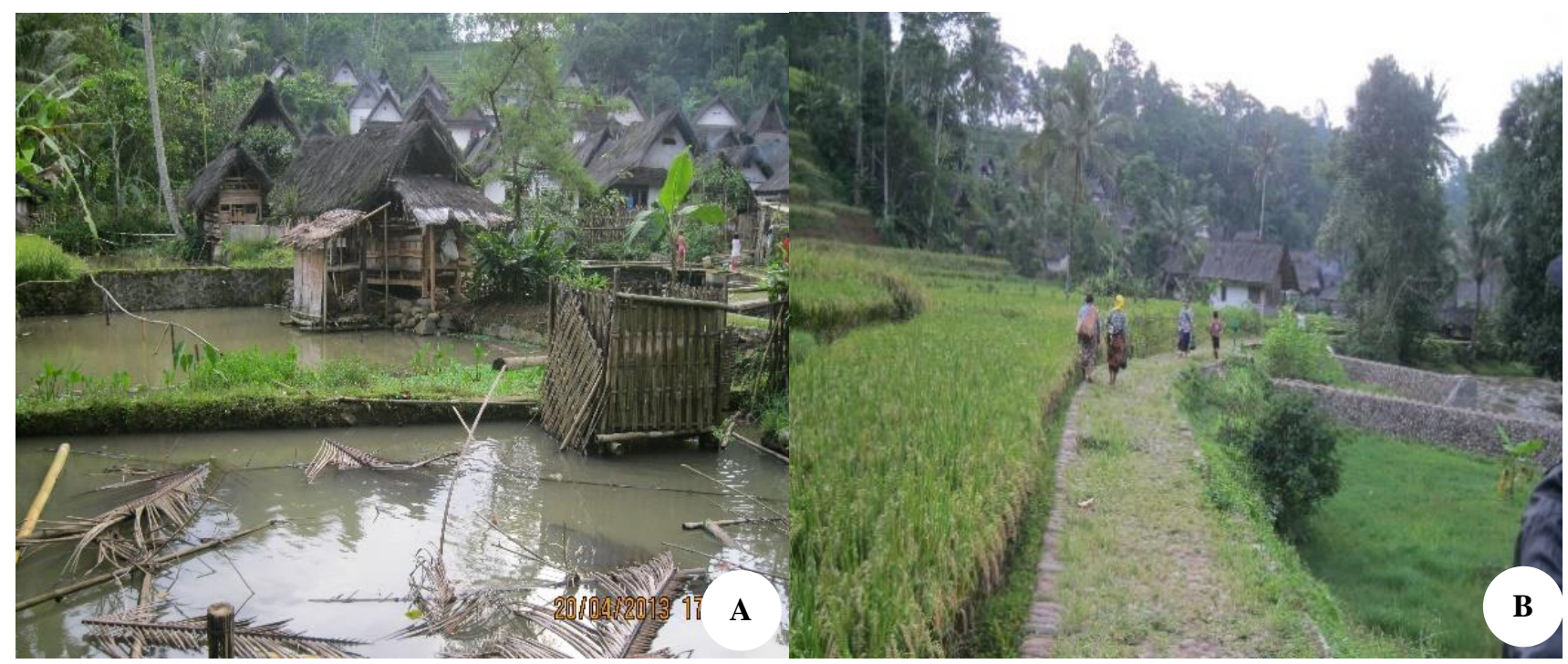

Figure 2.A. The settlement area consists of stilt traditional houses and homegardens that is surrounded by fish ponds in Naga Hamlet, Tasikmalaya District, West Java, Indonesia, B. The wet rice field (sawah) is placed outside the settlement and fish ponds

The clean area consists of settlement area, mosque, special house to keep heirlooms (bale patemon), and rice barn, that has function as place for social interactions and religious activities among the members of Naga community. While the dirty area is located outside of the clean area and is bordered by Ciwulan River. The dirty area consists of fishpond where traditional bathroom is placed, cattle shed (kandang ternak), and mortar house (lesung) (Iskandar 2017). The agroecosystems can be divided into two types, namely wet rice fields (sawah) and upland agricultural lands in the form of traditional agroforestry system, mixed garden of annual and perennial crops of fruits and building materials, including bamboos (cf. Iskandar and Iskandar 2011; Iskandar et al. 2018a).

The ownership system of the homegarden, wet rice field, and mixed garden is based on lineage in which such lands are inherited from generation to generation based traditional and Islamic norms, and registered in government administration system (Yulianingsih 2002; Iskandar et al. 2018b; Partasasmita et al. 2019).

The population of Naga community in 2011 was 305 people, consisting of 103 households. Two years later, the population of Naga community increased to 325 people belong to 108 households. In 2017, based on village statistics data, the population of Naga community was 299 people, consisting of 152 males and 147 female and belong to 103 households (Table 1). These figures suggest that population of Naga community between 2011 and 2013 increased, but in 2017 the population of Naga community slightly decreased. It is caused by the limited extent for settlement area in Naga Hamlet, triggering some people to migrate to neighboring Naga Hamlets, but in the same village, in which they usually made new houses there. Since some people of Naga community have locally moved to neighboring areas, the carrying capacity of Naga Hamlet has not been exceeded. Empirically, it can be observed that there are no new houses built in the main settlement of Naga Hamlet that placed in the valley (Statistical data of Neglasari village 2017).
Table 1. The population of the Naga community, Tasikmalaya District, West Java, Indonesia from 2011 to 2017.

\begin{tabular}{ccc}
\hline Year & Population & Household \\
\hline 2011 & 305 & 103 \\
2013 & 325 & 108 \\
2017 & 299 & 103 \\
\hline
\end{tabular}

Source: Suganda (2006), and the hamlet statistical data of Naga (2013) and (2017)

The main livelihood of Naga community is farmer. In addition to farmer, some people of this community have additional livelihoods, including making crafts from bamboo, producing palm sugar, and trading.

\section{Procedure}

Method used in this study was mixed-method of qualitative and quantitative techniques with ethnobiological and ethnoecological approaches were applied (Martin 1995; Cunningham 2001; Albuquerque et al. 2014; Iskandar and Iskandar 2015; Iskandar 2018). Some techniques in this study included field observation, semistructured interview, structured interview, and making plots of bamboo vegetation.

Observation was conducted to observe local environment and general condition of the settlement, wetrice fields, mixed garden, and forests. The semi-structured interviews or deep interviews with key informants was to obtain qualitative data on various aspects of bamboos, including species and variations (landraces), utilization, traditional cultivation, and traditional conservation of bamboo (Martin 1995; Wang et al. 2008; Creswell 2010; Singh et.al. 2015; Iskandar 2018). The key informants included informal leaders, old farmers, bamboo craftsmen and craftswomen, bamboo traders, and village middlemen. An interview guideline was used when conducting deep interviews with such informants. 
The structured interviews were conducted using questionnaires to randomly selected respondents. Total number of respondents was determined using formula by Lynch et al. (1974) and is presented below:

$$
n_{t}=\frac{N_{t} \cdot z^{2} \cdot P(1-P)}{N_{t} \cdot d^{2}+Z^{2} \cdot P(1-P)}
$$

Where:

$$
\begin{array}{ll}
\mathrm{n}_{\mathrm{t}} & \text { : Total samples or respondents } \\
\mathrm{N}_{\mathrm{t}} & \text { : Total number of households in Naga community } \\
\mathrm{Z} & \text { : Value of normal variable }(1,96) \\
\mathrm{P} & \text { : Maximum Probability }(0,5) \\
\mathrm{d} & \text { : Sampling error }(0,1)
\end{array}
$$

Based on total households of Naga community of 103 households, total respondents calculated using formula above resulted in 33 households. Heads of households and/or wife were interviewed using questionnaires.

To identify bamboo species based on the botanical identification, some bamboo samples or bamboo specimens were collected (cf. Rugayah et al. 2004) as herbarium and brought to botanical laboratory, Department of Biology, Padjadajaran University. Species of bamboos were then identified using books by Widjaja (2001), and Dransfield and Widjaja (1995). Vegetation structure of bamboo was analyzed by making nested sampling plots (Peran 2008, Cundaningsih et al. 2015; Iskandar and Iskandar 2016).

Qualitative data collected by observation and semistructured interviews were then analyzed by crosschecking, summarizing, synthesizing, and made narrative, descriptive and evaluative analysis. Quantitative data collected by structured interviews were analyzed by simple and descriptive statistics (Iskandar 2018).

Vegetation structure of bamboos was analyzed by calculating SDR (Summed Dominant Ratio), which is relative frequency (FR) and relative dominance (DR) (Nuwata 1974; Iskandar and Iskandar 2016) and presented as below:

$$
S D R=\frac{F r+D r}{2}
$$

Where,

$\mathrm{F}=$ Absolute frequency

$\mathrm{Fr}=$ Relative frequency

$\mathrm{D}=$ Absolute dominance, individual number of certain species is divided by total individual of all species

Dr =Relative dominancy, relative dominance of certain species is divided by relative dominance of all species

\section{RESULTS AND DISCUSSION}

\section{Species and variations (landraces) of bamboos}

\begin{tabular}{|c|c|}
\hline Vernacular name & Botanical name \\
\hline Haur hejo & $\begin{array}{l}\text { Bambusa vulgaris Schrader ex } \\
\text { Wendland var. vulgaris }\end{array}$ \\
\hline Haur koneng & $\begin{array}{l}\text { Bambusa vulgaris Schrader ex } \\
\text { Wendland var. striata (Lodd. ex Lindley) } \\
\text { Gamble }\end{array}$ \\
\hline Awi tali & $\begin{array}{l}\text { Gigantochloa apus (J. A \& J. H. } \\
\text { Schultes) Kurz }\end{array}$ \\
\hline Awi tamiyang & Schizostachyum iraten Steudel \\
\hline Awi surat & $\begin{array}{l}\text { Gigantochloa pseudoarundinacea } \\
\text { (Steudel) Widjaja }\end{array}$ \\
\hline $\begin{array}{l}\text { Awi temen or awi } \\
\text { ater }\end{array}$ & Gigantochloa atter (Hassk.) Kurz \\
\hline $\begin{array}{l}\text { Awi wulung or awi } \\
\text { hideung }\end{array}$ & Gigantochloa atroviolacea Widjaja \\
\hline
\end{tabular}

Based on interviews with the informants, direct survey in mixed-garden, and vegetation analysis, there were 7 species and variations (landraces) of bamboo in Naga Hamlet (Table 2).
Table 2. Various species and landraces of bamboo recorded in Naga Hamlet, Tasikmalaya District, West Java, Indonesia

Seven species and landraces of bamboos in Naga Hamlet is lower than in Karangwangi village, Cidaun Subdistrict, Cianjur District, West Java with 13 species (Partasasmita et al. 2017a) and that in Bali with 18 species and landraces (Arinasa and Peneng 2013).

The diversity of species and landraces of bamboos in Karangwangi village is higher because this study was not only located in agroecosystem types of homegardens and mixed-garden but also in forest area, namely Bojonglarang Jayanti Nature Reserve. As such, the scale is different. Some species of bamboo, including haur gereng (Bambusa blumeana), awi cangkoreh (Dinoclhoa scandens) and awi lengka (Gigantochloa harsskaliana) were predominantly found in the nature reserve instead of homegarden and mixed-garden (An'amillah 2016).

With regard to the diversity of Bamboo, the Naga is lower than Bali, because the Naga is a hamlet, whereas Bali is an island. Indeed, the Naga is different from Bali in that it has rarely bamboo species used for traditional rituals, whereas Bali has some endemic species and Bali's community are strongly embedded with bamboos as there are various bamboos traditionally used for rituals (Arinasa 2005; Arinasa and Peneng 2013).

Some species and landraces of bamboo were documented in Naga Hamlet, namely awi tali (Gigantochloa apus), awi surat (G. pseudoarundinacea), awi temen/awi ater (G. atter) and haur hejo (Bambusa vulgaris) (Figure 4). Four species and landraces were predominantly found indicated by the high value of SDR (Summed Domain Ration) (Table 3). These species and landraces, awi tali, awi surat and awi temen are considered as common species in West Java and reported and documented in mixed-garden of Soreang, South Bandung (Christanty et al. 1986), bamboo garden of Sumedang (Savlona 2006), and Karangwangi (Partasasmita et al. 2017a). 
Table 3. Summed of Dominant Ratio (SDR) value of bamboo species recorded at the mixed garden of Naga Hamlet, Tasikmalaya District, West Java, Indonesia

\begin{tabular}{|c|c|c|}
\hline Species and landraces & $\begin{array}{l}\text { Vernacular } \\
\text { name }\end{array}$ & $\begin{array}{l}\text { SDR }^{*} \\
(\%)\end{array}$ \\
\hline $\begin{array}{l}\text { Bambusa vulgaris Schrader ex } \\
\text { Wendland var. striata (Lodd. ex } \\
\text { Lindley) Gamble }\end{array}$ & Haur koneng & 2.93 \\
\hline $\begin{array}{l}\text { Bambusa vulgaris Schrader ex } \\
\text { Wendland var. vulgaris }\end{array}$ & Haur hejo & 6.46 \\
\hline $\begin{array}{l}\text { Gigantochloa apus (J. A \& J. H. } \\
\text { Schultes) Kurz }\end{array}$ & Awi tali & 48.78 \\
\hline Gigantochloa atroviolacea Widjaja & $\begin{array}{l}\text { Awi wulung, } \\
\text { awi hideung }\end{array}$ & 4.56 \\
\hline Gigantochloa atter (Hassk.) Kurz & $\begin{array}{l}\text { Awi temen, awi } \\
\text { ater }\end{array}$ & 12.59 \\
\hline $\begin{array}{l}\text { Gigantochloa pseudoarundinacea } \\
\text { (Steudel) Widjaja }\end{array}$ & Awi surat & 19.46 \\
\hline Schizostachyum iraten Steudel & Awi tamiyang & 5.24 \\
\hline
\end{tabular}

Note: *Summed Dominant Ratio

Based on the survey of bamboos at the mixed-gardens of Naga community, it can be revealed that bamboo with very high value of SDR is awi tali (Gigantochloa apus) (SDR=48.78), indicating that these bamboo species have high individual number and wide distribution at the mixed gardens of Naga Hamlet. The awi tali has been predominantly cultivated by Naga community because this species is major source for building materials or bamboo woven materials. In addition, awi tali can properly grow in open place of wet tropical climate from low land to high land of 1,500 $\mathrm{m}$ above sea level (Arinasa dan Peneng 2013). Since the awi tali has long fibers, strong, and flexible, this bamboo species has been predominantly used for woven and craft raw materials (Ediningtyas and Winarto 2012; Arinasa and Peneng 2013).

In addition to awi tali, awi surat and awi temen also have high value of SDR, meaning that these species have high population and wide distribution since these species easily grow in moist area from low land to high lands (Arinasa and Peneng, 2013).

\section{Local knowledge on bamboos}

Based on local knowledge of Naga community, species and variation of bamboos can be classified into several groups, namely based on color of culm, size of stem diameter, bamboo reed wall thickness, edible and nonedible of bamboo shoot, utilization types, economic or selling price, and ecological functions (Table 4).

In term of color, it has been recognized as haur koneng (Bambusa vulgaris var. striata) that has yellow with green line stem color; haur hejo (B. vulgaris), awi tali (Gigantochloa apus), awi temen/ater (G. atter) and awi tamiyang (Schyzostachium iraten) have green stem color; while awi wulung/awi hideung (G. atroviolacea) has black stem; and awi surat (G. pseudoarundinacea) has green with white line stem color (Figure 4).

Based on size of bamboo reed, bamboos can be divided into three types, namely big (ageung), medium (sedeng), and small (alit). The awi ageung has diameter of more than $10 \mathrm{~cm}$, awi sedeng has diameter $5-10 \mathrm{~cm}$; and awi alit has diameter $2-5 \mathrm{~cm}$. For example, bamboo species categorized as big are awi surat (G. pseudoarundinacea); medium are haur koneng (Bambusa vulgaris var. striata), haur hejo (B. vulgaris), awi tali (Gigantochloa apus) and awi temen/ater (G. atter); and small is awi tamiyang (Schyzostachium iraten).

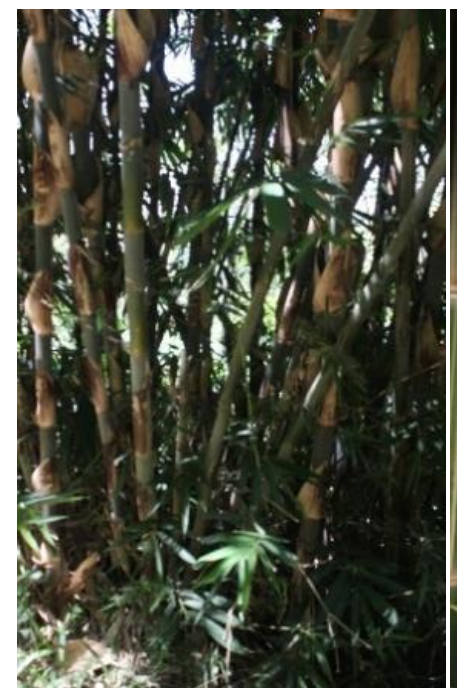

A

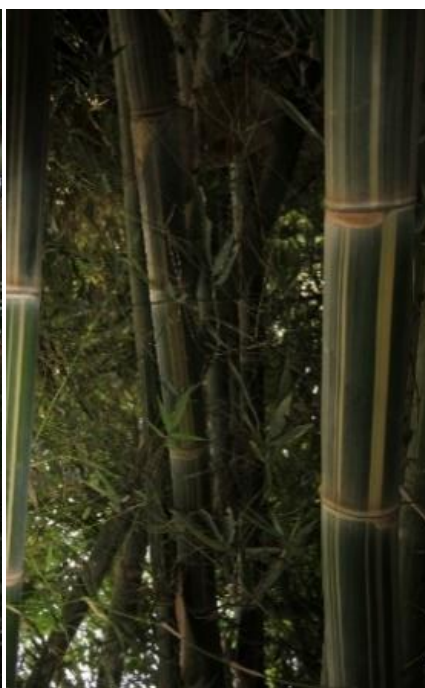

$\mathbf{B}$

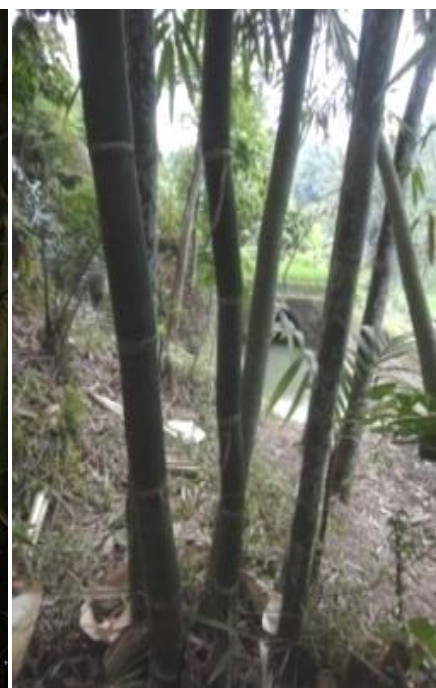

C

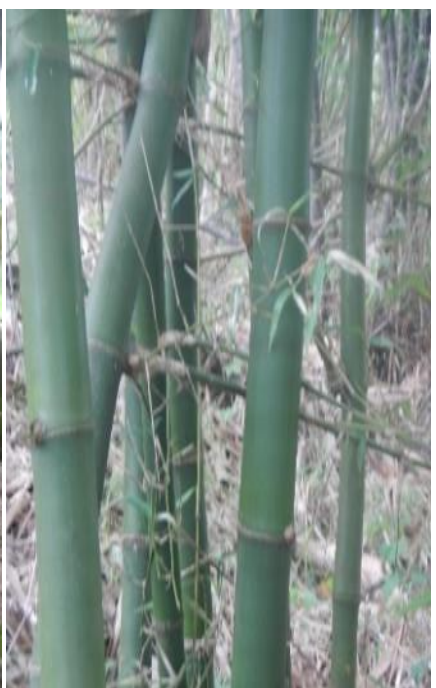

D

Figure 4. Various bamboos found and utilized by Naga community, Tasikmalaya District, West Java, Indonesia. A. Gigantochloa apus (J. A \& J. H. Schultes) Kurz/ Awi tali, B. Gigantochloa pseudoarundinacea (Steudel) Widjaja/Awi surat, C. Gigantochloa atter (Hassk.) Kurz/Awi temen or awi ater), D. Bambusa vulgaris Schrader ex Wendland var. vulgaris/haur hejo 
On the basis of the thickness of reed wall, bamboos can be divided into 2 categories, namely thick (kandel) and thin (ipis). The firs category has reed wall of $10-20 \mathrm{~mm}$, such as haur koneng (Bambusa vulgaris var. striata), haur hejo (B. vulgaris) dan awi surat (G. pseudoarundinacea), the second category has reed wall of less than $10 \mathrm{~mm}$, such awi tali (Gigantochloa apus), awi temen/ater (G. atter), awi wulung/awi hideung (G. atroviolacea) and awi tamiyang (Schyzostachium iraten).

Based on edible and non-edible of bamboo shoot, bamboos can be classified into two categories, namely surat (G. pseudoarundinacea) and awi temen/ater (G. atter), while other bamboos are categorized as non-edible bamboo shoot. According to perception of informants in Naga community, bamboo shoot with tasty and sweet is awi temen/awi ater. This perception is similar to that of Munziri et al. (2013) who mentioned that the bamboo shoot of $G$. atter has a smooth texture and sweet taste. Based on culinary, the bamboo shoot of awi ater has delicious to eat and is commonly used as vegetable (Edinintyas and Winarto (2012).

Based on selling price of bamboo per stem (saleunjeur), bamboos can be divided into two categories, cheap and expensive. The cheap bamboo is that can be sold at the price of Rp 5,000.00 per stem (leunjeur), and expensive is bamboo with price of $\mathrm{Rp} 15,000-25,000$ per stem (leunjeur). In addition, bamboos can be divided based on utilization and functions, such as building materials, woven, household appliances, traditional music instruments, and ecological functions (Table 4).

In regard to the straightness of the reed and the thickness of the reed, bamboos can be classified into two groups, namely haur which has a straight culm and awi which have a crooked culm (Tables 4-5). Based on botanical classification, haur is grouped as Bambusa genus, while awi is non-Bambusa group.

It can be concluded that the traditional ways of identification and classification of bamboo species by Naga community (i.e., folk classification) is similar to that carried out by Kebon Kalapa community, Sumedang District, which identify the variations of bamboo based on straightness of stem/culm, culm color and culm/stem size edible bamboo shoot, such as haur hejo (B. vulgaris), awi

(Savlona 2006). The identification of bamboo species is also in accordance with that of Karangwangi community, Cianjur District, who identify bamboo based on red color, stem/culm size, cultivation and utilization (Setiawati et al. 2017). Folk classification refers to how member of a language community (i.e., the 'folk') name and categorize plants and animals (Brown 2000). As proposed by Brent Berlin et al. (1974) cited by Iskandar (2018) concerning ethnobiological rank, Naga community recognized four levels of language to describe the order of plants and animals, similar with common Sundanese community. Level 0 refers to beginner rank in which Naga community have special term on plants (tutuwuhan) and crops (pepelakan). In context of bamboo trees, they are predominantly domesticated (pepelakan) instead of growing naturally/wild (tuwuhan). The next level, level 1 refers to rank life-form in which bamboos are categorized as trees (kakayon or tangkal) instead of grass (jukut) or shrubs (rungkun). Thus, Naga community is similar to other communities across culture in the world in that it has local knowledge in 4 levels of traditional classification of bamboos (Brent Berlin et al. 1974; Iskandar 2018), particularly good local knowledge on specific and varietal using analogy with species and sub-species based on the botanical classification. For instance, the bamboos can be traditionally divided into two species namely awi dan haur, and sub-species i.e., awi hideung and haur hejo (Table 6).

Table 6. Traditional classification system of bamboos by Naga community, Tasikmalaya District, West Java, Indonesia

\begin{tabular}{|c|c|c|c|}
\hline Level & Class & & Rank \\
\hline 0 & Tutuwuhan & & $\begin{array}{l}\text { Unique- } \\
\text { beginner }\end{array}$ \\
\hline 1 & Kakayon & & Life-form \\
\hline 2 & $\begin{array}{l}\text { Awi } \\
\text { (straight culm) }\end{array}$ & $\begin{array}{l}\text { Haur } \\
\text { (crooked culm) }\end{array}$ & Generic \\
\hline 3 & $\begin{array}{l}\text { Awi hideung } \\
\text { Awi tali } \\
\text { Awi tamiyang } \\
\text { Awi surat }\end{array}$ & $\begin{array}{l}\text { Haur hejo } \\
\text { Haur koneng }\end{array}$ & Specific \\
\hline
\end{tabular}

Table 5. Comparison of folk classification (emic view) to scientific classification (ethic view) of bamboo in Naga Hamlet, Tasikmalaya District, West Java, Indonesia

\begin{tabular}{|c|c|}
\hline $\begin{array}{l}\text { Folk classification of bamboo based on Naga community } \\
(\text { emic view })\end{array}$ & $\begin{array}{l}\text { Western botany classification } \\
\text { (ethic view) }\end{array}$ \\
\hline $\begin{array}{l}\text { Haur is recognized based on straight culm, thick } \\
\text { Haur hejo is recognized as culm-color green. } \\
\text { Haur koneng is recognized as culm-color yellow with green-strip }\end{array}$ & $\begin{array}{l}\text { Bambusa } \\
\text { Bambusa vulgaris Schrad. ex Wendl. var. vulgaris } \\
\text { Bambusa vulgaris Schrad. ex Wendl. var. vittata A. Rivière }\end{array}$ \\
\hline $\begin{array}{l}\text { Awi (crooked culm) } \\
\text { Big stem size }(\text { ageung })(115-20 \mathrm{~cm}) \text {, thick } \\
\text { Awi surat is recognized as culm-color green with white strip }\end{array}$ & Non-Bambusa (Schizostachyum) and Gigantochloa \\
\hline $\begin{array}{l}\text { Small stem size (alit) }(2-5 \mathrm{~cm}) \text {, thin (ipis) } \\
\text { Awi tamiyang is recognized as culm-color green }\end{array}$ & Schizostachyum iraten Steudel \\
\hline $\begin{array}{l}\text { Medium stem size (sedeng) }(\square 5-10 \mathrm{~cm}) \text {, thin } \\
\text { Awi tali is recognized as culm-color green) } \\
\text { Awi temen/ater is recognized as culm-color green) } \\
\text { Awi hideung is recognized as culm-color black) }\end{array}$ & $\begin{array}{l}\text { Gigantochloa apus (J.A. \& J.H. Schultes) Kurz } \\
\text { G. atter(Hassk.) Kurz } \\
\text { G. atroviolaceae Widjaja }\end{array}$ \\
\hline
\end{tabular}


Table 4. Characteristics of species and landraces of bamboo based on the local knowledge of Naga community, Tasikmalaya District, West Java, Indonesia

\begin{tabular}{|c|c|c|c|c|c|c|c|}
\hline \multirow{2}{*}{$\begin{array}{l}\text { Vernacular } \\
\text { names }\end{array}$} & \multicolumn{3}{|c|}{ Stem } & \multirow{2}{*}{$\begin{array}{c}\text { Edible and } \\
\text { non-edible of } \\
\text { bamboo shoot }\end{array}$} & \multirow{2}{*}{ Utilization } & \multirow{2}{*}{ Price } & \multirow{2}{*}{ Ecological function } \\
\hline & Color & Size & Thickness & & & & \\
\hline Haur hejo & Green (hejo) & Medium & Thick & Edible & Rancatan & Expensive & Ceblok, a stake on the ground/sawah \\
\hline Haur koneng & $\begin{array}{l}\text { Yellow (koneng) with } \\
\text { green stripes }\end{array}$ & Medium & Thick & Non-edible & Magic and ornamental plant & Expensive & Protection of soil erosion and water storage \\
\hline Awi tali & Green (hejo) & Medium & Thin & Non-edible & Weaving & $\begin{array}{l}\text { Cheap (Rp. } 5,000 \text { /stem } \\
\text { (saleunjeur) }\end{array}$ & Protection of soil erosion and water storage \\
\hline Awi tamiyang & Green (hejo) & $\begin{array}{l}\text { Small } \\
\text { (alit) }\end{array}$ & Thin & Non-edible & Flute & $\begin{array}{l}\text { Expensive }(\mathrm{Rp} \\
25.000 / \mathrm{stem})\end{array}$ & Protection of soil erosion in the steep slope \\
\hline Awi surat & Green with white stripes & $\begin{array}{l}\text { Big } \\
\text { (ageung) }\end{array}$ & Thin & Edible & $\begin{array}{l}\text { Karinding, calempun, and } \\
\text { building materials }\end{array}$ & $\begin{array}{l}\text { Expensive (Rp. } \\
25,000 / \text { stem) }\end{array}$ & Protection of soil erosion and water storage \\
\hline $\begin{array}{l}\text { Awi temen or awi } \\
\text { ater }\end{array}$ & $\begin{array}{l}\text { Green with white circle } \\
\text { of each internode }\end{array}$ & Medium & Thin & Edible & $\begin{array}{l}\text { Cup and edible bamboo } \\
\text { shoot }\end{array}$ & Expensive $(25,000 /$ stem $)$ & Protection of soil erosion and water storage \\
\hline $\begin{array}{l}\text { Awi wulung or awi } \\
\text { hideung }\end{array}$ & Black (hideung) & Medium & Thick & Non-edible & Gambang & $\begin{array}{l}\text { Expensive (Rp. 25,000/ } \\
\text { stem) }\end{array}$ & Protection of soil erosion and water storage \\
\hline
\end{tabular}


It can be concluded that in term of hierarchical botanical taxonomy, Naga community have a detailed knowledge up to level of species and sub-species in classifying bamboos, similar to other studies conducted by other scholars (Diamond and Bishop 2000; Iskandar et al. 2016).

\section{Utilization of bamboos}

Bamboos have some socio-economic, cultural, and ecological values for Naga Community. Some species and landraces have socio-economic for both subsistence and commercial uses for the Naga community. For subsistence uses, various bamboo species have been traditionally used for building materials, household appliances, agricultural and fishing tools, additional foodstuffs, and traditional musical instruments (Figures 5-6). For commercial uses, some bamboo trees have been made of handicrafts (e.g. woven containers), household appliances (e.g., palupuh, krei), traditional music instruments (karinding and flute (suling)) and these have been sold in Naga Hamlet or in markets outside of Naga Hamlet.

Based on structured interviews with respondents, it can be revealed that $90.91 \%$ of the respondents mentioned that bamboos provide economic benefits for both bamboo garden owners and bamboo craftsmen. Most informants $(81.82 \%)$ mentioned that bamboo trees can provide economic benefits, particularly when the bamboo trees are processed into various handicraft products, while $9.09 \%$ of respondents mentioned that bamboo trees can provide economic benefits by directly selling bamboo trees. Yet, several respondents $(9.09 \%)$ mentioned that bamboo did not provide economic benefits because they do not involve in making bamboo crafts. Instead, they do entrepreneurship activities, such as trade which might be perceived to get more economic benefits.

In addition to providing socio-economic benefits, bamboos also provide ecological functions. For example, Naga community perceived that bamboo of haur hejo (B. vulgaris) has function as soil ground reinforcement (pamageuh taneuh) to protect soil from erosion. The bamboo trees of haur hejo are predominantly planted by Naga community in river banks to protect erosion. Bamboo trees with dense canopy (hiyeum) are perceived by Naga community can provide oxygen (O2), shading and a cooler temperature. In addition, bamboo gardens can maintain water during dry season. Therefore, bamboo garden can provide ecosystem services, including soil protection from erosion, better air quality, carbon sink, land restoration, barrier of runoff penetration to soil, and wind protection (Nath et al. 2015).

Based on the respondents in Naga community, bamboos can be used for building materials (18.2\%), woven bamboo for containers $(4.5 \%)$, traditional music instruments (11.4\%), cooking utensils $(22.7 \%)$, agricultural tooling needs $(13.6 \%)$, livestock management $(6.8 \%)$, foodstuffs $(2.3 \%)$, and others $(20.5 \%)$, including traditional medicines, pickle tools, straps, ornamental plant, fish trap tools, and mystical beliefs (Figures 5-7).

The uses of bamboo by Naga community are similar to Karangwangi village community in which it has some functions, including building materials, household appliances, working tools, medicine, consumption, traditional music instruments, traditional games, decoration and ecological functions (Partasasmita et al. 2017a). However, there are also some differences in function of bamboo between Naga community and Karangwangi village community in which awi temen/ater or awi surat is traditionally used in both Naga for placing baby placenta by covered it with cloth and washed into a river, while awi tamiyang in Karangwangi village is traditionally used for making sumpit to hunt animals, including birds (Iskandar et al. 2016; Partasasmita et al. 2017a).

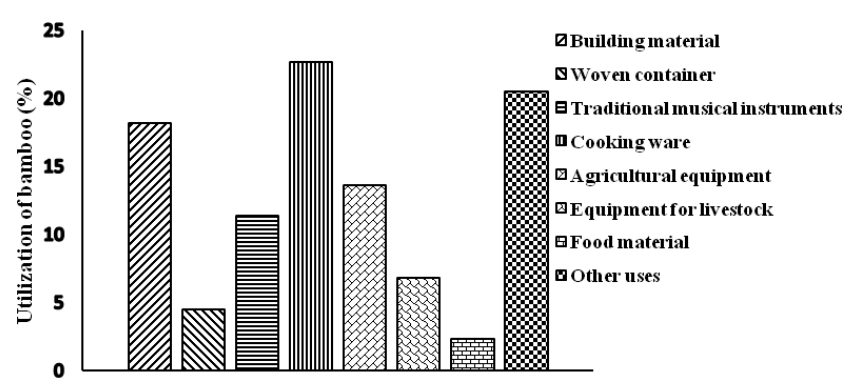

Figure 6. Composition on the uses of bamboos by Naga community, Tasikmalaya District, West Java, Indonesia

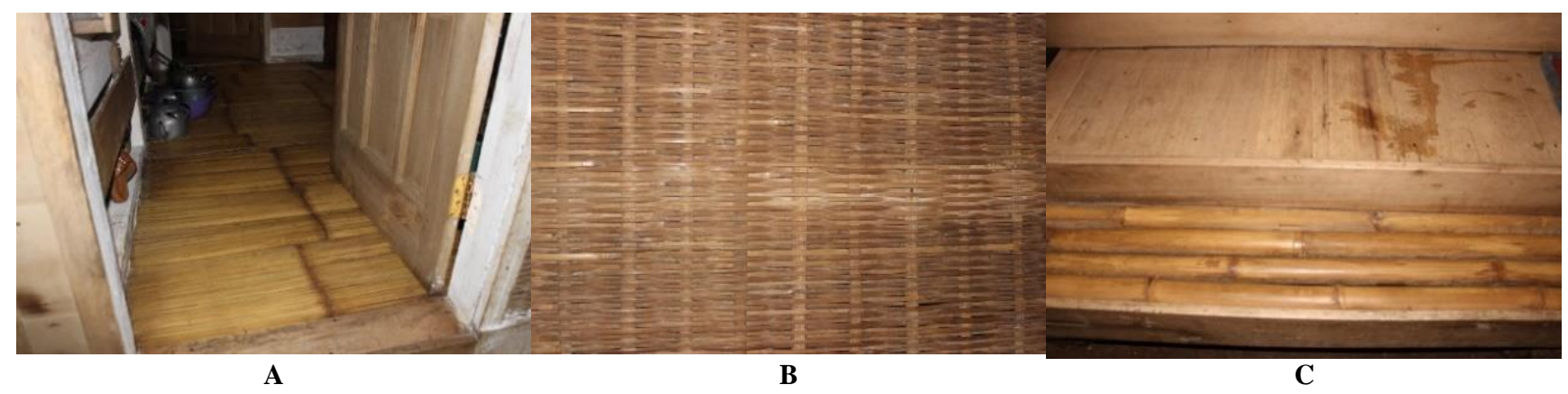

Figure 5. Bamboos used as building materials in traditional house (A) bamboo floor/palupuh, (B) house wall/bilik and (C) veranda/teras) in Naga Hamlet, Tasikmalaya District, West Java, Indonesia 


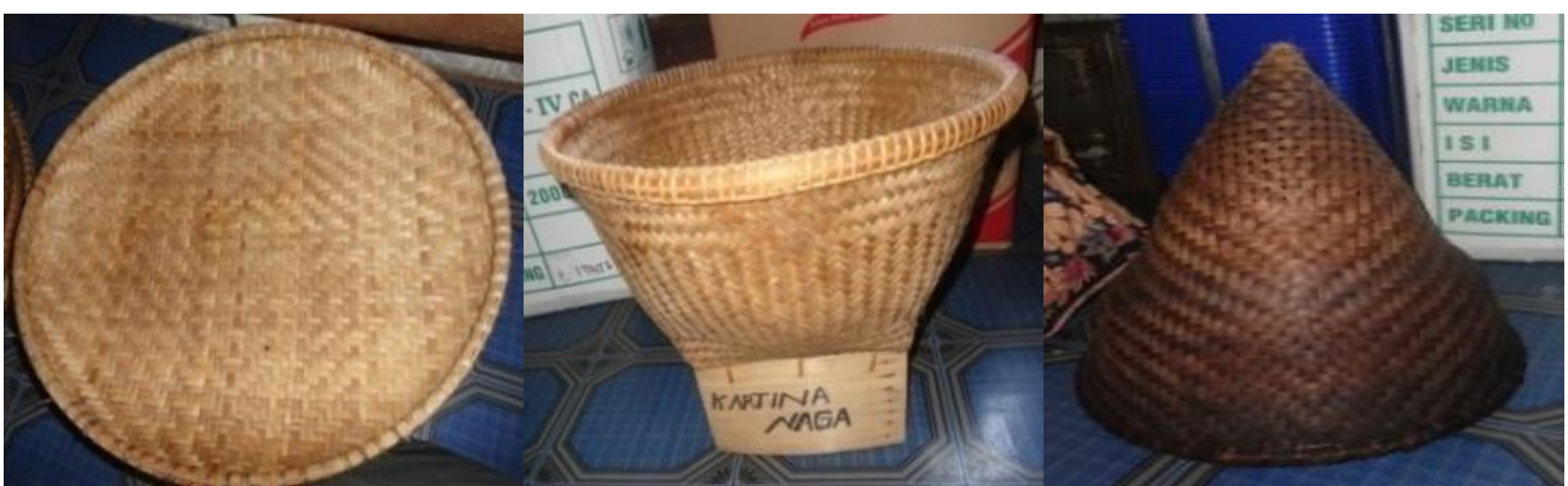

A

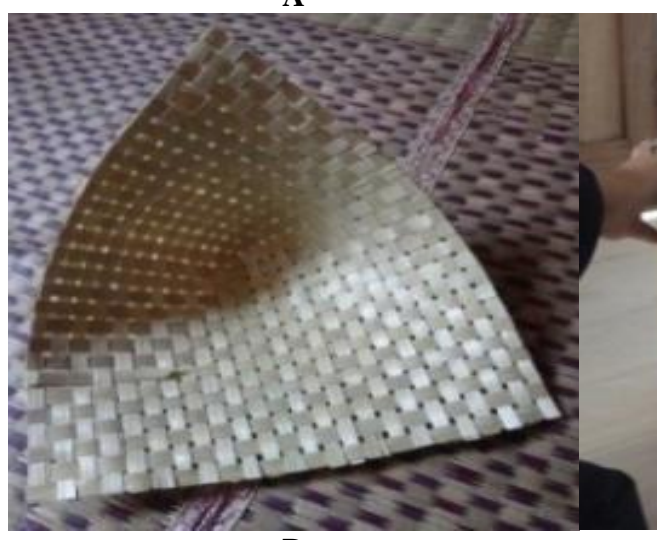

D

B

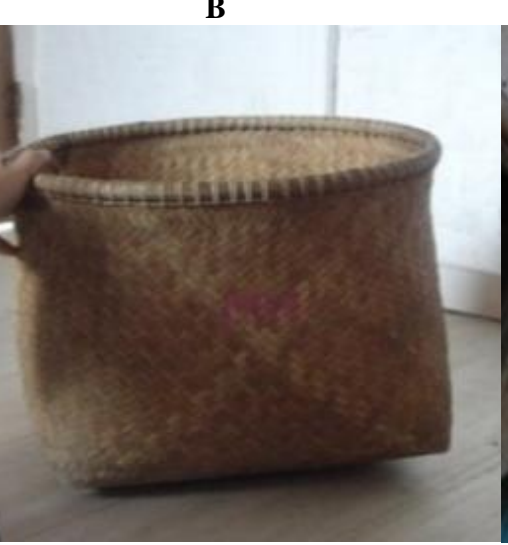

$\mathbf{E}$

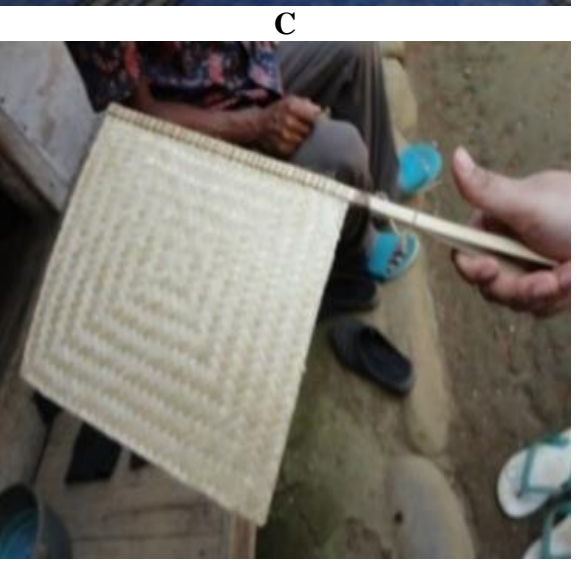

$\mathbf{F}$

Figure 7. Various household appliances made of bamboo materials in Naga Hamlet, Tasikmalaya District, West Java, Indonesia. A. Nyiru, B.Boboko, C. Aseupan, D. Pengki, E. Tolombong, F. Hihid

\section{Management of bamboo plants in the mixed garden}

Traditional management of bamboos by Naga community consists of seedling propagation, land preparation, maintenance, pest management, harvesting, and conservation.

\section{Seedling propagation}

Traditionally, bamboo seedling is prepared in two ways, namely by cutting bamboo stem or old culm (melak buluh) and planting rhizome (melak tunggul). For propagation, Naga community select young culm of about two years old (dua adi). Part of rhizome or culm used as seedling has two buds. The rhizome for seedling is taken from bamboo clump and placed in special place. This traditional technique is similar to that described by Ediningtyas and Winarto (2012) in which cut rhizome is selected from young culm that has two years old and has two internodes. The rhizome or young culm is cleaned from fiber roots and planted in different place. Naga community predominantly use cutting rhizome because it is easily to obtain from bamboo stumps. Although the planting of cutting rhizome can be considered rapidly growing and stronger, using this technique is rather difficult because the rhizome must be separated from the bamboo stump (Ediningtyas and Winarto 2012).

\section{Land preparation}

Based on information from Naga community, before planting bamboo rhizome on the garden, land preparation must be conducted. For example, shrubs and Imperata grass must be cut using hoe. The location for planting bamboo is selected, particularly that close to water sources and being moist, such as river bank. This is intended to provide good condition to new rhizome to adapt with new environment. The biomass of grass and shrubs are used as compost for organic fertilizer. Planting of bamboo is usually conducted before the rainy season or during the rainy season. Unlike planting other crops, cultivating bamboo do not require intensive land preparation and is considered to be labor efficient.

\section{Planting}

Traditionally, planting of bamboo conducted by Naga community has two techniques, namely planting of rhizome (melak tunggul) and planting of stem (melak batang). Planting of rhizome is carried out by separating of rhizome base (bongkol akar) from bamboo clump and then planted in the prepared land. The technique of using rhizome is better than that using stem cutting because the rhizome has still nutrient stored in its base which can avoid desiccation (Ediningtyas and Winarno 2012). To increase the growing success bamboo branch cuttings can be used 
growth regulators substance, such as NAA and coconut water (Setiawati et al. 2018).

On the other hand, planting of old culm/stem has several steps including plugging the stem on the ground upright, being tilted, and being placed horizontally depending on the bamboo species. Based on the perception of Naga community, differences in how to grow bamboo will cause differences in the growth of the bamboo. For example, haur hejo (Bambusa vulgaris) is commonly planted by plugged on the ground upright because haur hejo has thick reed, as such by planting upright the young culm will grow quickly. In contrast, planting of bamboo culm horizontally would produce thin reed and not strong culm. Planting of bamboo by stem cutting technique has disadvantage of being resistant to low bamboo reeds, and prone to drought. However, stem cutting is easy because it can use any section of internodes/old culm (Ediningtyas and Winarno 2012)

\section{Maintenance}

Bamboo is different from other plants in that it can grow without special maintenance. Based on structured interview with respondents, $54.54 \%$ of respondents mentioned maintenance of bamboos by clearing weeds, $39.4 \%$ by providing fertilizer while $6.06 \%$ ) do no maintenance at all. Bamboos can be cultivated in the village with very efficient inputs, including labor, seed/culm, fertilizer, and pesticide. As such, this practice can be considered as practicing LEISA (Low External Inputs and Sustainable Agriculture) in which most of inputs are originated internally from local farm or village with and direct action. This can ensure sustainability to support village farming system with ecological sound, economically viable, and locally adaptable (Reijntjes et al. 1992).

\section{Pest control}

According to informants of Naga community, bamboo trees are more resistant to pest attack. It has been known only one kind of pest that usually attack bamboo plants, a kind of caterpillar which is locally called as cangkilung (Erionata thrax). Cangkilung predominantly attacks bamboo's internode and lives inside of the internode, causing hollow and broking bamboo reeds. Another pest usually attacks harvested bamboo and is locally named as opong (termite-Isoptera). Opong is usually attacked bamboo culms that are properly harvested, for example, bamboo culms that still contain a lot of water.

Cangkilung is eradicated by cutting infected bamboo trees to avoid this pest to spread to other bamboos. In some cases, cangkilung are commonly used for fishing bait. The harvested bamboo tree that has been attacked by opong cannot be used for building materials and other functions, but it might be used for firewood.

\section{Harvesting}

Harvesting old bamboo trees are conducted by cutting old culms. Traditionally, harvesting bamboo trees are carefully undertaken to avoid destruction to other bamboo culms within one bamboo clump. Some aspects including time, age and maturity, and how to harvest bamboo tree must be considered by Naga community when harvesting bamboo trees.

Based on semi-structured interview, it can be revealed that all respondents $(100 \%)$ harvest bamboo when they need bamboo trees to fulfill household needs, including building materials, traditional music instruments, and so on. Appropriate time to harvest bamboo trees is after $10 \mathrm{am}$ until afternoon because at that time water contents in bamboo tree have dropped or decreased, so it will be more durable when used. According to the beliefs of Naga community, bamboo trees cannot be harvested at any day and the harvesting is best on Monday and Thursday, while harvesting on Sunday is prohibited. As a result, bamboo population in the village can properly be maintained by local wisdom (Iskandar 1998; Iskandar 2018).

According to Ediningtyas and Winarno (2012), appropriate time to harvest bamboo trees is during the dry season as during this period bamboo trees do not contain a lot of water and not grow to be young culms. Moreover, bamboo trees harvested in the dry season would have strong and be resistant to pests. In addition, during the rainy season, generally young culms are at growing phase from old rhizomes, therefore, harvesting bamboo trees during this period will disturb the young culms.

According to informants of Naga community, the appropriate age for harvesting bamboo is after awi saadi, meaning that when a bamboo clump produces new shoots or new bamboo culms. Awi saadi is a stage when the bamboo is at medium age, or not too young or too old, which is suitable for handicrafts such as bamboo weaving. Bamboo for weaving is ready to harvest at around one year of age. In addition, bamboo can be harvested when it is truly old and it is used as raw materials for making traditional musical instruments and building materials. To determine whether bamboo is young, medium, or old, the community do it by beating bamboo stems with a machete in which older bamboo will create a louder sound if beaten by a machete.

According to Sutiyono (2013), bamboo trees can be harvested for the first time at the age of 5 years and carried out on third generation. Then, bamboo harvesting can be carried out each year on fourth, fifth generation and so on. The cutting of bamboo trees is carried out during the dry season to get good stem quality.

In term of cutting technique, Naga community usually harvest bamboo trees by selective cutting instead of total cutting. By doing so, availability of bamboo trees for various purposes of household daily needs can be sustained. Conversely, if bamboos are totally cut, it needs time approximately 3-5 years to be readily harvested. Based on interviews with informants and respondents, the technique of felling bamboo is done by leaving a few centimeters above the ground and keeping the old stump to get new shoots growing. The technique of cutting bamboo with selective cutting systems is known in Jatuluhur area, Purwakarta District as ketengan or ontrek (Indrayono et al. 1983). Ontrek is a cutting pattern where bamboo is selected based on certain stem diameter sizes in the market (Indrayono et al. 1983). This is in accordance with Nadeak 
(2009), in which selective cutting activities are carried out to maintain the sustainability of bamboo clumps. Usually, old culms are in the middle of a clump. Because the shape of the cluster is sympodial, it is quite difficult to do cutting. Therefore, cutting must be carried out carefully to avoid damaging the stems occurred during cutting which will impact the production of stems per clump.

According to Achmed (1957) cited by Sutiyono et al. (1996), to ensure the survival of the clumps, a number of old culms need to have remained. The ways to cut bamboo with selective cutting systems are as follows: the stem is cut less than $30 \mathrm{~cm}$ above the ground, and bamboo shoots and roots are observed so as not disturbed. The advantage of selective cutting is to facilitate subsequent cutting and provide opportunities for bamboo shoots to develop properly. In cutting, it is recommended that cutting rotation is carried out every three years (Ediningtyas and Winarno 2012). Therefore, it is necessary to divide three cutting blocks and each block only experiences cutting once for three years. As such, bamboo culms can be produced every year.

\section{Conservation of bamboo}

Based on local knowledge of Naga community, they have terms in relation to traditional conservation of environment, including bamboo gardens, such as "live with nature, not live in nature". Unlike common Sundanese people, Naga community have expression on the importance of bamboos for them by saying "without bamboos the land dries, and bamboos can support our life". As such, Naga community have strongly maintained local ecosystems as expressed in "live with nature", and also conserved bamboo garden as "bamboos can support their life".

Traditionally, indigenous management practices have been conducted to conserve both bamboo species and bamboo garden as explained above. As a result, despite bamboo trees are frequently used, the plants will remain sustainable in nature as Naga community has traditionally been harvesting bamboos based on their traditional ecological knowledge embedded in their local culture (Iskandar 2018).

Naga community cultivate bamboo trees not only to fulfill their daily needs, but also they understand the role of bamboo in protecting soil against erosion and storing groundwater. This is in accordance with Hendersun (1997) cited by Nadeak (2009), that bamboo is special plant serving as soil and water conservation, as well as mitigating the risk of landslide and abrasion of river bank in village ecosystems. Since bamboos produce a lot of litter, soil fertility can be maintained and runoff during the rainy season can be reduced. This increase water infiltration into soil to maintain hydrological system function in watershed level (Christanty 1989).

In conclusion, this study recorded 7 species and landraces of bamboos in Naga community, namely Bambusa vulgaris Schard ex Wendl. var. vulgaris (haur hejo), Bambusa vulgaris Schard ex Wendl. var. striata (Lodd. ex Lindley) Gamble (haur koneng), Gigantochloa apus (J.A. \& J.H. Schult) Kurz. (awi tali), Gigantochloa pseudoarundinacea (Steud) Widjaja (awi gedelawi gombong), Gigantochloa atter (Hassk) Kurz. (awi temen), Gigantochloa atroviolacea Widjaja (awi hideung) and Schizostachyum iraten. Steud (awi tamiyang). Bamboos are traditionally used as building materials, woven for container, traditional musical instruments, equipment for cooking, agricultural and livestock purposes, foodstuffs, and others. Bamboo plants in the community garden have been traditionally managed based on traditional ecological knowledge, consisting of land preparation, planting, maintenance, pest control, harvesting, and utilization. Conservation of bamboo has been traditionally implemented by Naga community, including selective cutting of bamboo trees instead of clear-cutting, being harvested during appropriate time, and not being converted to other land use types.

\section{ACKNOWLEDGEMENTS}

The authors gratefully acknowledge financial support from the Grant of Penelitian Dasar Unggulan Perguruan Tinggi Kemenristek Dikti, year of 2017-2018. We also would like to thank the informal leaders and people of Naga community who kindly assisted us in providing various data concerning bamboo aspects.

\section{REFERENCES}

Albuquerque UP, Paiva de Lucena RF, Ramos MA, de Lucena RFP, Alcenar NL. 2014. Methods and techniques used to collect ethnobiological data. In Albuquerque UP, Cruz da Cunha LVF, de Lucena RFP, Alves RRN (eds.). Methods and Techniques in Ethnobiology and Ethnoecology. Springer Science + Business Media, New York.

An'amillah A. 2016. Traditional Knowledge of Villagers in Karangwangi Village Subdistrict Cidaun District Cianjur on Diversity Species, Utilization, and Management of Bamboo. [Scription] Department of Biology, Faculty of Mathematics and Natural Sciences, Padjadjaran University [Indonesian].

Arinasa IBK, Peneng IN. 2013. Various bamboo species and their potentials. LIPI Press, Jakarta. [Indonesian].

Arinasa IBK. 2005. Diversity and utilization of bamboo species in village of Tigawasa, Bali. Biodiversitas 6 (1): 17-21 [Indonesian].

Berkes F. 2008. Sacred Ecology. 2nd ed. Taylor \& Francis, New York.

Berlin B, Breedlove D, Raven P. 1974. Principles of Tzeltal plant classification: An introduction of the botanical ethnography of a Mayan-speaking people of Highland Chiapas. Academic Press, New York.

BPG (Bamboo Phylogeny Group). 2012. An update tribal and subtribal classification of the bamboo (Poaceae: Bambusoidea). In: Proceedings of the 9th World Bamboo Congress, 10-12 April 2012, Belgium.

Brown CH .2000 Folk classification, an introduction. In: Minnis PE (ed.) Ethnobotany: a reader. University of Oklahoma Press, Norman, OK.

Buckingham KC, Liangru W, Yiping L. 2014. Can't see the (Bamboo) forest for the tree: examining bamboo's fit within international forestry institutions. Ambio 43: 770-778.

Christanty L, Abdoellah OS, Marten GG, Iskandar J. 1986. Traditional agroforestry in West Java: the pekarangan (homegarden) and kebuntalun (annual-perenial rotation) cropping system. in traditional agriculture in Southeast Asia: a human ecology perspective. West view Press, Colorado, USA.

Christanty L. 1989. Analysis of the Sustainability and Management of the Talun-Kebun system of West Java, Indonesia. [Dissertation] Faculty of Graduate Studies, the University of British Columbia, Vancouver, Canada. 
Creswel JW. 2013. Research design, qualitative-quantitative and mixed methods approaches. Sage, Los Angeles.

Cundaningsih N, Saputri SR, Arosyanti E, Amalia A, Irawan B. 2015 Study on ecology of black bamboo as material of angklung music in West Java. Pros. Sem. Nas. Masy. Biodiv. Indon. 1 (7): 1600-1604. [Indonesian].

Cunningham AB. 2001. Applied ethnobotany: people, wild plant use and conservation. Earthscan Publications Ltd. London dan New York.

Dransfield, Widjaja EA. 1995. Plant Resources of South-East Asia. Vol. 7. Bamboos. Prosea, Bogor.

Ediningtyas D, Winarto V. 2012. Want to know on bamboo? Forestry extension Center, the Ministry of Forestry, Jakarta. [Indonesian].

Indrayono E, Asdak C, Nelwan PR. 1983. Interaction between human and bamboo in Jatiluhur: Implication on bamboo as an alternative strategy for conservation in Upland area. Internal Research Report, Institute of Ecology, Padjadjaran University, Bandung. [Indonesian].

Iskandar BS, Iskandar J, Partasasmita R. 2018b. Strategy of the Outer Baduy community of South Banten (Indonesia) to sustain their swidden farming traditions by temporary migration to non-Baduy areas. Biodiversitas 19: 453-464

Iskandar J and Iskandar BS. 2011. Agroecosystem of Sundanese people. Buku Kiblat Utama Press, Bandung [Indonesian].

Iskandar J, BS Iskandar, Partasasmita R. 2016. The local knowledge of the rural people on species, role and hunting of birds: case study in Karangwangi village, West Java, Indonesia. Biodiversitas 17 (2): 435446.

Iskandar J, Iskandar BS, Partasasmita R. 2018a. Review: The impact of social and economic change on domesticated plant diversity with special reference to wet rice field and home-garden farming of West Java, Indonesia. Biodiversitas 19: 502-514

Iskandar J, Iskandar BS. 2015. Botanical study: diversity of food crops on swidden farming (huma) to support the food security of Baduy community. Pros Sem Nas Biodiv 1(6): 1265-1272 [Indonesian].

Iskandar J, Iskandar BS. 2017. Various plants of traditional rituals: ethnobotanical research among Baduy community. Biosaintifica 9 (1) $114-125$

Iskandar J, Iskandar BS. 2018. Ethnoecology, rice biodiversity, and modernization of rice farming: case study on Baduy community and Naga community. J Biodjati 3 (1): 47-62 [Indonesian]

Iskandar J, Iskandar BS.2016. Plant architecture: village homegarden structure and the urban green open space. Teknosain, Yogyakarta [Indonesian]

Iskandar J. 1998. Swidden Cultivation as a Form of Cultural Identity: the Baduy Case. [Dissertation], University of Kent at Canterbury, England.

Iskandar J. 2012. Ethnobiology and Sustainable Development. Revised Edition. AIPI Bandung, Puslitbang KPK LPPM Unpad, Bandung. [Indonesian].

Iskandar J. 2017. Human Ecology and Sustainable Development. Revised Edition PSMIL, Unpad, Bandung. [Indonesian].

Iskandar J. 2018. Ethnobiology, Ethnoecology and Sustainable Development. Plantaxia, Yogyakarta [Indonesian].

Kelchner SA. 2013. Higher level phylogenetic relationships within the bamboos (Poaceae: Bambusoideae) based on five plastid markers Mol Phyllogen Evol 67: 404-413.

Lynch F, Holsteiner RM, Cover CL. 1974. Data Gathering by Social Survey. Philippine Social Science Council, Quezon City.

Martin GJ.1995. Ethnobotany: a methods manual. Chapman \& Hall, London.

Mudzakkir A. 2012. Between traditional community and people: community of Naga in changes. J Maarif 7 (1): 104-116 [Indonesian].

Munawaroh S, Astuti IP. 2000. Role of botany in supporting ex-situ conservation of botanical garden. National Seminar Proceeding on Utilization of Biodiversity and Environmental Management. Faculty of Biology, University of Satyawacana, Salatiga [Indonesian].

Munziri. 2013. Botanical study among Dayak Kanayatn in Saham village, Landak District. J Protobiont 2 (3): 112-116 [Indonesian].

Nadeak MN. 2009. Cultivation and utilization of bamboos in Balumbang Jaya village, West Bogor district and Rumpin village, Rumpin subdistrict, Bogor district, West Java [Internal Report]. Department of Silviculture, Faculty of Forestry, Bogor Agricultural University, Bogor. [Indonesian]
Nath AJ, Lal R, Das AK. 2015. Managing woody bamboo for carbon farming and carbon trading. Global Ecol Conserv 3: 654-663

Nuwata M. 1974. Ecological problems in weed research. In Soerjani M (ed), Tropical weeds, some problems, biology and control. Biotrop Bull. 2: 215. Proc. First Indonesian Weed Science Conf, Biotrop, Bogor.

Partasasmita R, An'Amillah A, Iskandar J, Mutaqin AZ, Annisa, Ratningsih N. 2017a. Karangwangi people's local knowledge of bamboo and its role: implications for management of cultural keystone species. Biodiversitas 18 (1): 275-282.

Partasasmita R, Iskandar J, Rukmana PM. 2017b. Naga people's (Tasikmalaya District, West Java, Indonesia) local knowledge of variations and traditional management farm of village chickens. Biodiversitas 18 (2): 834-843.

Partasasmita R, Iskandar BS, Nuraeni S, Iskandar J. 2019. Impact of the green revolution on the gender's role in wet rice farming: A case study in Karangwangi Village, Cianjur District, West Java, Indonesia. Biodiversitas 20: 23-36.

Peran SB. 2008. Various bamboos recorded in around of river and mountain of Hulu Banyu village. J Hutan Tropis Borneo (23) [Indonesian].

Permana S, Iskandar J, Partasasmita P. 2018. Local knowledge on rice variations (landraces) of the Naga community, West Java, Indonesia. Asian J Ethnobiol 1 (1): 1-8.

Permana S. 2015. Naga community, traditional ecological knowledge, and conservation of biodiversity. Plantaxia, Yogyakarta [Indonesian].

Reijntjes C, Haverkort B, Waters-Bayer A. 1992. Farming for the future: an introduction to low-external-input and Sustainable Agriculture. The MacMillan Press Ltd, London.

Rugayah, Widjaja EA, Praptiwi. 2004. Guideline for collecting data. Puslitbio LIPI. Bogor [Indonesian].

Saringendyanti E. 2008. Kampung Naga, Tasikmalaya dalam Mitologi: Upaya Memaknai Warisan Budaya Sunda. Fakultas Sastra, Universitas Padjadjaran, Bandung. [Indonesian]

Savlona M. 2006. Study on utilization bamboo species in the community of Kebon Kalapa village, Cisarua sub-district, Sumedang District, West Java (Internal Report), Department of Biology, Faculty of Mathematics and Natural Sciences, Padjadjaran University [Indonesian].

Setiawati T, Keliat APR, Budiono R, Partasasmita R, Iskandar J. 2018. Influence of NAA and coconut water with variation of soaking duration on the growth of yellow bamboo branch cutting. Nusantara Bioscience 10: 178-182.

Singh RJ, Singh A, Garnett ST, Zander KK, Lobsang, Tsering D. 2015. Agroecosystem management and livelihoods in Arunachal Pradesh, India. Environ Manag 55: 187-204.

Sujarwo W. 2018. Bamboo resources, cultural values, and ex-situ conservation in Bali, Indonesia. Reinwardtia 17 (1): 67-75.

Sutiyono, Hendromono, Marfu'ah, Ihak. 1996. Cultivation technique of bamboo. Research Center for Forest Product, Bogor [Indonesian].

Sutiyono. 2013. Cultivation of bamboo. Research Center and Development of Enhancement Productivity of Forest, Bogor [Indonesian].

Van der Lugt P, Lobokinov M. 2008. Markets for bamboo product in the west. Bois et Forest Tropiques 295 (1): 83-90.

Van der Lugt P, Vogtlander JG, Brezet JC. 2010. Life cycle assessment and carbon sequestration: the environmental impact of industrial bamboo products. Preceding IXth World Bamboo Congress.

Vogtlander JG, Van der Lugt P, Brezet JC. 2010. The sustainability of bamboo product for local and western European applications, LCAs and land-use. J Cleaner Product 18: 1260-1269.

Wang G, Innes JL, Dai S, He G. 2008. "Achieving sustainable rural development in Southern China: the contribution of bamboo forestry". Int J Sustain Develop World Ecol 15 (5): 484-495

Weijun F, Jiang P, Zuhao K, Zhou E, Yongfu L, Jiasan W, Huaqiang D. 2014. The carbon storage and ist spatial variation in Anji county of southeastern China. J. Soil Sediment 14: 320-329.

Widjaja EA. 2001. Identification of bamboos in Java. Research Center and Development of Biology, Lipi, Jakarta [Indonesian].

Yulianingsih D. 2002. Ethnobotany study on Naga community, Negalasari village, Salawu sub-district, Tasikmalaya District, West Java Province. (Internal Report), Faculty of Forestry, Bogor Agricultural University, Bogor. [Indonesian]. 